\title{
The impact of mouth-rinsing using chlorhexidine gluconate $0.2 \%$ to the amount of plaque-causing bacteria colonies in fixed orthodontic users
}

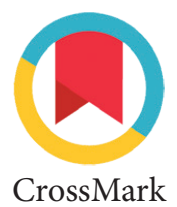

\author{
Melinda N. Leonarto,, Eddy H. Habar
}

\section{Abstract}

Objective: The aim of this study is to know the impact of mouthrinsing using chlorhexidine gluconate $0.2 \%$ with the number of plaque-causing bacterial colonies in fixed orthodontic users. One of the most common problems is malocclusion. The solution is to do orthodontic treatment but the side effect is very susceptible to having poor mouth hygiene due to oral microflora which has changed and the difficulty to clean the appliance.

Material and Methods: This research type is quasi-experimental with pretest and posttest with control group design. The sample, which consist of 30 college students of fixed orthodontic users was divided into two groups where the first group was given the chlorhexidine gluconate $0.2 \%$ and the second group was given aqua dest. A swab on teeth samples were taken before treatment, on 7th day and 14th day to observe the number of bacteria colonies by cup-counting method at Microbiology Laboratory, Pharmacy Faculty of Hasanuddin University. Results: The results of repeated ANOVA and post hoc bonferroni test by using SPSS program (23rd version) showed that the value baseline was $333.86 \pm 11.8$, on 7 th day was $229.26 \pm 6.3$ and on 14 th day was $127.40 \pm 7.8$ with the $p$-value $=0.000$. The result of general linear model analysis on 7 th day and on 14 th day was $p=0.000$ which means there is significant decrease in the number of bacteria colonies. Conclusion: Mouth-rinsing using chlorhexidine gluconate $0.2 \%$ significantly affects the amount of plaque-causing bacterial colonies in fixed orthodontic users $(p<0.05)$ with the percentage drop is $61.84 \%$.
Department of Orthodontics, Faculty of Dentistry, Hasanuddin University, Makassar, Indonesia
${ }^{*}$ Correspondence to:

Melinda N. Leonarto, Department of Orthodontics, Faculty of Dentistry, Hasanuddin University, Makassar, Indonesia melinda.leonarto@aiesec.net

Received: 16 April 2017 Revised: 09 June 2017 Accepted: 21 June 2017 Available Online: 01 August 2017

Keywords: Gargle, Chlorhexidine gluconate 0.2\%, Plaque, Fixed orthodontic

Cite this Article: Leonarto MN, Habar EH. 2017. The impact of mouth-rinsing using chlorhexidine gluconate $0.2 \%$ to the amount of plaquecausing bacteria colonies in fixed orthodontic users. Journal of Dentomaxillofacial Science 1(3): 91-94. D0l: 10.15562/jdmfs.v1i3.320

\section{Introduction}

The percentage of oral health problems has increased from year to year. This is evidenced from RISKESDAS 2007 and 2013 by increasing from $23.2 \%$ to $25.9 \% .^{1}$ The most common oral health problems are tooth decay, periodontal disease and malocclusion. ${ }^{2}$ Currently malocclusions are third in the ranking of priorities among the problems of dental public health worldwide, surpassed only by dental cavity and periodontal diseases. ${ }^{3}$ The prevalence of malocclusion in Indonesia is still very high, approximately about $80 \%$ of the population. ${ }^{4}$

The term malocclusion was first invented by Guilford, it is defined as an abnormality that causes disfigurement or impedes function and requires treatment. The malocclusion might be associated with one or more of the following: malalignment of individual's teeth in each arch, malrelationship of the dental arches relative to the normal occlusion: in anteroposterior, vertical, or transverse planes. Occlusion is defined as the manner in which the upper and lower teeth intercuspates with each other in all mandibular positions and movements. It is a result of neuromuscular control of the components of the masticatory system, periodontal structures, maxilla, mandible, temporomandibular joints, and their associated muscles and ligaments. ${ }^{5}$
The orthodontic treatment aims to adjust the position of teeth to the right tooth curve. Thus, efficiency of chewing function, face harmony, oral health, dentofacial aesthetics, and tooth position stability can be improved. The orthodontic treatment usually takes 2-3 years. ${ }^{4}$ It has been shown that orthodontic treatment induces changes in the oral environment such as an increase in bacterial concentrations like number of mutans: streptococci and lactobacillus spp., alterations in $\mathrm{pH}$, salivary buffering capacity, salivary flow, and dental plaque of these patients. ${ }^{6-10}$ There is an increase in the volume of dental plaque as well as an increase in the number of bacteria and the concentration of carbohydrate in each milligram of plaque. ${ }^{7}$ Furthermore, all of these changes are closely associated with hygienic and dietary behavior of the patient. ${ }^{9}$

Patients undergoing fixed orthodontic treatment can lead to enamel demineralization, causing white spots, tooth decay and gingivitis. ${ }^{8}$ The number of demineralization injuries increased significantly during the first six months and continued to increase up to 12 months. ${ }^{9}$ The placement of orthodontic appliances increases retention areas and irregular surfaces of brackets and bands provide protection to microorganisms from physical forces. ${ }^{9-11}$ 
It encourage the accumulation of dental plaque and the proliferation of cariogenic and periodontopathic microorganisms, increasing the risk of caries and periodontitis. ${ }^{12}$ Therefore, cleaning becomes more complicated, which favors plaque accumulation. In addition, dietary behaviors significantly influence demineralization: if fermentable substances are continuously ingested, acid production by plaque exceeds neutralization by the saliva and demineralization occurs. When carbohydrate availability is in excess, $\mathrm{pH}$ drops and remains at this lower level., ${ }^{911}$

Patients wearing orthodontic appliances must be encouraged to take good care of their oral cavity. Perfect cleaning of teeth in patients with fixed appliance takes at least ten minutes, which requires considerable care and discipline habits. Orthodontist should be aware of their patients' oral hygiene problems since one of the main goals of orthodontics is to achieve dental and skeletal harmony while preserving healthy teeth and support surfaces. ${ }^{8}$

Chlorhexidine is an antimicrobial agent. ${ }^{13}$ It is commercially available in the forms of mouth rinse, gel, varnish, toothpastes, sprays, and sugar free chewing gum. ${ }^{13,14}$ It acts on the inner cytoplasmic membrane; hence, it is a membrane active type of substance. It is dicationic at $\mathrm{pH}$ levels above 3.5. It prevents plaque accumulation; hence, it is an antiplaque and antigingivitis agent and reduces the adherence of porphyromonas gingivalis to epithelial cells. It can be bacteriostatic or bactericidal depending on the dose. It acts against a wide array of bacteria including gram-positive and gram-negative bacteria, dermatophytes, and lipolytic viruses. ${ }^{13}$ Chlorhexidine gluconate is a cationic biguanide which is bacteriostatic in low and bactericidal in higher concentrations. ${ }^{13,15}$ Chlorhexidine gluconate at a concentration of $0.2 \%$ is regarded as the gold standard in the reduction of plaque formation and as a local bacterial compound. ${ }^{15}$

The objective of this study was to know the impact of mouth-rinsing using chlorhexidine gluconate $0.2 \%$ with the number of plaque-causing bacteria colonies in fixed orthodontic users.

\section{Material and Methods}

This research type was quasi-experimental, pretest, and posttest test design with control group design was conducted among subjects undergoing orthodontic treatment. The study was conducted under the approval of Medical Ethical (1637/H04.8.4.5.31/ PP36-KOMETIK/2016) Faculty of Medicine, Hasanuddin University, Makassar, Indonesia.

Thirty samples were selected for this study from students at Faculty of Dentistry. Those who met the following inclusion criteria were enrolled in the study: patients who were undergoing fixed orthodontic treatment for more than 3 months, there was no known hypersensitivity to chlorhexidine and there was no known medical problem. Additionally, subjects being on antibiotic treatment, current users of tobacco in any form, current users of any other mouth rinse, having active periodontal disease, or any other problems which could affect oral microbial flora were excluded. They were explained about the study and informed consent was obtained.

All the subjects were randomly divided to 2 groups: chlorhexidine group $(n=15)$ and aqua Dest or distilled water group $(n=15)$. The subjects were instructed to rinse with $10 \mathrm{ml}$ of mouth rinse for $30 \mathrm{~s}$ after brushing their tooth, twice daily (after breakfast and before going to bed) for 14 days. Sampling was performing in three steps: baseline, on 7th day, and on 14th day. All the microbial tests was carried out in the Faculty of Microbiology Laboratory of Pharmacy, Hasanuddin University.

One day before the sample was taken, researcher had to make transport medium in laboratory and store it in 30 vial bottles. Then it was brought on the day the samples were taken at Faculty of Dentistry. The subjects were instructed not to take food before the researcher took swabs of their teeth. Samples were taken by cotton swab and were stored in vial bottles one-by-one. Furthermore, all of those bottles were taken to laboratory for incubation at $37^{\circ} \mathrm{C}$ for 24 hours.

About one $\mathrm{ml}$ from transport medium was dropped in to petri dish then BHIA medium was poured in to it, so the bacteria could grow up after incubation at $37^{\circ} \mathrm{C}$ for 24 hours again. The bacterial colony were counted by using cup count method. The data were analyzed according to parametric: repeated ANOVA test, post hoc Bonferroni test, and general linear model test by using SPSS version 23 (SPSS Inc, Chicago II, USA). The statistical significance level was determined at $\mathrm{p}<0.05$.

\section{Results}

Table 1 presents the number the mean values of bacteria colonies in both groups: chlorhexidine gluconate $0.2 \%$ group and aqua Dest (distilled water) group. A comparison of bacteria colonies within each group, showed the reduction effect significantly in chlorhexidine group. A significant reduction in chlorhexidine group between baseline, on 7 th day and on 14th day is shown in table 2.

Table 3 shows the comparison of the effectiveness between the stages in both group and the result on 7 th day and on 14th $(\mathrm{p}=0.000)$ was significant. Furthermore the effect of rinsing chlorhexidine on 7 th day is $31.32 \%$, between 7 th day and 14 th day is $44.43 \%$, and on 14 th day is $61.84 \%$ table 4 . 
Table 1 The number of bacteria colonies in chlorhexidine gluconate $0.2 \%$ and aqua Dest group

\begin{tabular}{lccccc}
\hline & & Baseline & On 7th day & On 14th day & \\
\cline { 3 - 5 } & $\mathbf{N}$ & $\begin{array}{c}\text { Mean } \pm \\
\text { Standard } \\
\text { deviation }\end{array}$ & $\begin{array}{c}\text { Mean } \pm \\
\text { Standard } \\
\text { deviation }\end{array}$ & $\begin{array}{c}\text { Mean } \pm \\
\text { Standard } \\
\text { deviation }\end{array}$ & p \\
Group & 15 & $333.8 \pm 11.8^{*}$ & $229.2 \pm 6.3^{*}$ & $127.4 \pm 7.8^{*}$ & $0.000^{\mathrm{a}}$ \\
$\begin{array}{l}\text { Chlorhexidine } \\
\text { gluconate 0.2\% }\end{array}$ & 15 & $334.3 \pm 11.5^{*}$ & $332.8 \pm 11.6^{*}$ & $335.1 \pm 10.6^{*}$ & $1.000^{\mathrm{b}}$ \\
Aqua Dest & & & & & \\
\hline
\end{tabular}

Explanation:

${ }^{\star}$ Normality test Shapiro-Wilk test; $\mathrm{p}>0.05$ : normal distribution data

${ }^{\star}$ Homogeneity test Levene; $\mathrm{p}>0.05$; variance of homogeneous data

a Repeated ANOVA test; $\mathrm{p}<0.05$ : significant

${ }^{b}$ Repeated ANOVA test; $\mathrm{p}>0.05$ : no significant

Table 2 Post Hoc Bonferroni test in chlorhexidine gluconate $\mathbf{0 . 2 \%}$ group

\begin{tabular}{llcl}
\hline Baseline & On 7th day & 104.600 & $0.000^{*}$ \\
On 7th day & On 14th day & 306.567 & $0.000^{*}$ \\
& Baseline & -104.600 & $0.000^{*}$ \\
On 14th day & On 14th day & 101.867 & $0.000^{*}$ \\
& Baseline & -206.467 & $0.000^{*}$ \\
\hline
\end{tabular}

Explanation:

"Post Hoc Bonferroni test; $\mathrm{p}<0.05$ : significant

Table 3 General linear model test for bacteria colonies between group

\begin{tabular}{lccc}
\hline Group & Baseline & On 7th day & On 14th day \\
\hline $\begin{array}{l}\text { Aqua Dest } \\
\text { Chlorhexidine gluconate } 0,2 \%\end{array}$ & 0.914 & $0.000^{*}$ & $0.000^{*}$ \\
\hline
\end{tabular}

Explanation:

${ }^{*}$ General linear model test; $\mathrm{p}<0.05$ : significant

Table 4 Percentage reduction of bacterial colonies in chlorhexidine group

\begin{tabular}{lccc}
\hline Time rinsing & & On 7th day & On 14th day \\
\hline Baseline & Baseline & $31.32 \%$ & $61.84 \%$ \\
On 7th day & - & - & $44.43 \%$ \\
On 14th day & - & - & - \\
\hline
\end{tabular}

\section{Discussion}

During orthodontic treatment, practicing satisfactory oral hygiene is a difficult task for orthodontic patients because of brackets and wires. A failure to maintain proper oral hygiene leads to tooth damage. Therefore, levels of cariogenic pathogens should be constantly reduced during the active phase of orthodontic treatment if a chemical agent can be used. ${ }^{16}$ This study was proposed to know the impact of mouth-rinsing using chlorhexidine gluconate $0.2 \%$ with the number of plaque-causing bacteria colonies in fixed orthodontic users.
In this study there was a reduction in the number of bacterial colonies in the treatment group and statistical analysis showed significant differences. Several studies have proved the effectiveness of chlorhexidine gluconate $0.2 \% \cdot{ }^{15-20}$ Sari E et al. ${ }^{16}$ evaluated the effects of $0.2 \%$ chlorhexidine gluconate on streptococcus mutans and lactobacilli levels in saliva. They reported that in combination with mechanical plaque removal, $0.2 \%$ chlorhexidine gluconate is an important therapeutic agent in controlling the streptococcus mutans and lactobacilli levels of orthodontic patients with fixed appliances.

Furthermore, Yeturu et al. ${ }^{17}$ reported that the highest percentage of reduction of plaques scores was in chlorhexidine group. Aloe vera and chlorine dioxide showed almost similar reductions in plaque and gingivitis when compared to chlorhexidine over a period of 15 days. The reduction in plaque scores in Aloe vera group could be attributed due to the active compounds like aloesin, aloin, aloeride, flavonoids, saponin and sterols. These compounds also have shown antibacterial, anti-inflammatory, and antioxidant properties causing reduction in both plaque and gingival scores. Similarly, chlorine dioxide also reported to have antibacterial properties by disrupting protein synthesis, inactivating enzymes, and misbalancing electrolytes within cell membranes hence, from the results of the study it can be concluded that chlorine dioxide and aloe vera can be a suitable and economical alternative for chlorhexidine.

Likewise, Saffari et al..$^{18}$ investigated the effect of chlorhexidine and persica mouthwash on colonization of streptococcus mutans on fixed orthodontics O-rings. The authors concluded that persica cannot be a good alternative for chlorhexidine and patients undergoing orthodontic treatment need to use mouth rinse like chlorhexidine to inhibit of bacterial colonization so they can improve their periodontal health during treatment. Similarly, Abouassi et al. ${ }^{15}$ showed aerobic and anaerobic salivary bacteria were significantly reduced after $3 \mathrm{~min}$ of incubation in $0.2 \%$ chlorhexidine. Since chlorhexidine is a strongly cationic molecule it can react with anionic chemicals, resulting in inactivation of antimicrobial activity. The $\mathrm{pH}$ of unstimulated saliva ranges between 5.8 and 7.1 with an average daily flow between 1 and 1.5 in healthy individuals. The results showed that human saliva can inactive the antibacterial activity of chlorhexidine against some oral bacterial, so the addition of $7 \%$ ethanol can compensate this effect.

Most bacteria, tooth surfaces, and mucous membranes are anions that will bind strongly to the cation chlorhexidine. ${ }^{19}$ The mechanism of action is mainly by binding to microbial cell membranes and damaging the surface structure, leading to an osmotic imbalance and precipitation of cytoplasm causing cell death. ${ }^{17}$ The attachment of plaque 
bacteria will mature within 24 hours, and chlorhexidine may inhibit the early adhesion of plaque bacteria on tooth surface. In a study performed by Arief et al. ${ }^{19}$ it was found that the superiority of chlorhexidine can be detected during 48 and 72 hours.

Chlorhexidine is dicationic at $\mathrm{pH}$ levels above 3.5. The mechanism of action of chlorhexidine is that the bacterial cell wall is negatively charged containing sulfates and phosphates, while the dicationic positively charged chlorhexidine is attracted to the negatively charged bacterial cell wall with specific and strong adsorption to phosphate containing compounds, which will alter the integrity of the bacterial cell membrane and chlorhexidine is attracted to the inner cell membrane. By increasing the concentration of chlorhexidine there is progressive damage to the membrane. When chlorhexidine binds to the phospholipids in the inner membrane there is leakage of low molecular weight compounds like potassium ions, and cytoplasm of the cell are chemically precipitated. There is coagulation and precipitation of the cytoplasm by the formation of the phosphate complexes which include adenosine triphosphate and nucleic acids. The bactericidal stage is irreversible. ${ }^{13}$

Chlorhexidine groups have the ability to reduce the amount of plaque-causing bacterial colonies in fixed orthodontic users. The percentage reduction of bacteria colonies on 14 th days was $61.84 \%$, on 7 th days was $31.32 \%$, and between 7 th and 14 th day was $44.43 \%$. Higher percentage values along with the length of use of chlorhexidine gluconate $0.2 \%$ showed a good effect for a person with oral hygiene. This was similar to PF Wagmare et al. ${ }^{20}$ who compared the efficacy of turmeric mouthwash and chlorhexidine gluconate mouthwash in prevention of gingivitis and plaque formation. The result showed the percentage reduction of total bacterial count in chlorhexidine group on 21 st day was $89.94 \%$. In this study, the subject in chlorhexidine group complained of alteration in taste. This was similar with previous study by Arief et al. ${ }^{19}$

\section{Conclusion}

Mouth-rinsing using chlorhexidine gluconate $0.2 \%$ significantly affects the amount of plaque-causing bacteria colonies in fixed orthodontic users $(p<0.05)$ with the percentage drop is $61.84 \%$.

\section{Conflict of Interest}

The authors report no conflict of interest.

\section{References}

1. Department Kesehatan Republik Indonesia. Riset Kesehatan Dasar (Riskesdas) Jakarta: Badan Penelitian dan Pengembangan Kesehatan Kementrian RI; 2013.
2. Oley AB, Anindita PS, Leman MA. Kebutuhan perawatan ortodonti berdasarkan index of treatment need pada usia remaja 15-17 tahun. Jurnal Ilmiah Kedokteran Gigi USU 2015;3: 292-297.

3. Garbin AJI, Perin PCP, Garbin CAS, et al. Malocclusion prevalence and comparison between the angle classification and the dental aesthetic index in scholars in the interior of São Paulo state-Brazil. Dent Press J Orthod 2010;15: 95.

4. Herniyati, Narmada IB, Soetjipto. Effects of robusta coffee (coffea canephora) brewing on levels of RANKL and TGFB1 in orthodontic tooth movement. Dent J 2016;49: 144.

5. Ibrahim HA, Abu affan AH. Prevalence of malocclusion and orthodontic treatment needs in down syndrome Sudanese individuals. Ortho J of Nepal 2014;4: 32-37.

6. Maret D, Marchal-sixou C, Vergnes J-N, et al. Effect of fixed orthodontic appliances on salivary microbial parameters at 6 months: a controlled observational study. J Appl Oral Sci 2014;22: 38-43.

7. Shukla C, Maurya RK, Singh V, et al. Evaluation of change in Streptococcus mutans colonies in microflora of the Indian population with fixed orthodontic appliance. Dent Res J 2016;13: 309-314.

8. Bardal PAP, Olympio KPK, Bastos JRM, et al. Education and motivation in oral health-preventing disease and promoting health undergoing orthodontic treatment. Dent Press J Orthod 2011;16: 95-102.

9. Valdes EN, Carrillo EL, Solis CEM, et al. Tooth demineralization and associated factors in patients on fixed orthodontic treatment. Sci rep 2016;6: 1-6.

10. Cantekin K, Celikoglu M, Karadas M, et al. Effects of orthodontic treatment with fixed appliances on oral health status: a comprehensive study. J Den Sci 2011;6: 235-238.

11. Chen W, Zhou Y. Caries outcomes after orthodontic treatment with fixed appliance: a longitudinal prospective study. Int J Clin Exp Med 2015;8: 2815-2822.

12. Wang SY, Yang YS, Chang HP. The effect of an oral hygiene instruction intervention on plaque control by orthodontic patients. J Dent Sci 2007;2: 45-51.

13. Balagopal S, Arjunkumar R. Chlorhexidine: the gold antiplaque agent. J Pharm Sci \& Res 2013;5: 270-274.

14. Prahasanti C. Efektifitas obat kumur chlorhexidine, essential oil, triclosan-sodium fluoride dalam pencegahan pembentukan bakteri plak. J Dentofasial 2014;13: 55-58.

15. Abouassi T. Does human saliva decrease the antimicrobial activity of chlorhexidine against oral bacteria? BMC Research Notes 2014;7: 1-6.

16. Sari E, Brichi I. Microbiological evaluation of $0.2 \%$ chlorhexidine gluconate mouth rinse in orthodontic patients. Angle Orthod 2007;77: 881-884.

17. Yeturu SK, Archarya S, Urala AS, et al. Effect of aloe vera, chlorin dioxide and chlorhexidine mouth rinses on plaque and gingivitis: a randomized controlled trial. J Oral Biol \& Craniofac Res 2016;6: 54-58.

18. Saffari F, Ardakani MD, Zandi H, et al. The effect of chlorhexidine and perisca mouthwash on colonization of streptococcus mutans on fixed orthodontics O-rings. J Dent Shiraz Univ Med Sci 2015;16: 54-57.

19. Arief EM, Adnan NBD, Awang RAR. The effect of chlorhexidine and triclosan on undisturbed plaque formation for 72 hours duration. J Dentofasial 2010;9: 1-5.

20. Waghmare PF, Chaudhari AU, Karhadkar VM, et al. Comparative evaluation of turmeric mouthwash and clorhexidine gluconate mouthwash in prevention of plaque formation and gingivitis: a clinical and microbiological. J Contemp Dent Pract 2014;12: 221-224.

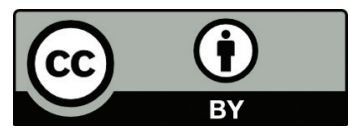

This work is licensed under a Creative Commons Attribution 